\title{
Late Glacial and Holocene temperature changes at Egelsee, Switzerland, reconstructed using subfossil chironomids
}

\author{
Isabelle Larocque-Tobler • Oliver Heiri • \\ Michael Wehrli
}

Received: 23 January 2009/Accepted: 8 July 2009/Published online: 24 July 2009

(C) The Author(s) 2009. This article is published with open access at Springerlink.com

\begin{abstract}
A temperature reconstruction using chironomids was attempted at Egelsee, Switzerland, a site where pollen and macrofossil records showed a correspondence between vegetation and climatic changes inferred by other proxies in Europe. The general pattern of temperature changes inferred from chironomids during the Late Glacial [i.e. cold temperatures between ca. 16,500 and $14,800 \mathrm{cal}$ $\mathrm{BP}$, close to present-day temperature between 15,000 and 13,000 cal BP and colder temperatures during the Younger Dryas (YD)], and the major temperature changes of the Holocene (i.e. the
\end{abstract}

\section{Larocque-Tobler}

Institut National de Recherche Scientifique (INRS),

Centre Eau, Terre et Environnement, 490 De La

Couronne, Quebec, QC G1K 9A9, Canada

O. Heiri

Palaeoecology, Institute of Environmental Biology,

Faculty of Science, Utrecht University, Budapestlaan 4,

3584 CD Utrecht, The Netherlands

e-mail: o.m.heiri@uu.nl

\section{Wehrli}

Institut für Pflanzenwissenschaften, Universität Bern, Altenbergrain 21, 3013 Bern, Switzerland

e-mail: michael.wehrli@ips.unibe.ch

I. Larocque-Tobler $(\bowtie)$

Oeschger Centre for Climate Change Research and Institute of Geography, University of Bern, Zähringerstrasse 25, 3012 Bern, Switzerland e-mail: larocque@giub.unibe.ch;

isabelle_larocque@ete.inrs.ca
Younger Dryas-Holocene transition and the Late Holocene cooling trend) at Egelsee, were mirrored in other European climate reconstructions using various proxies. However, the amplitude of temperature changes during the YD was smaller than reconstructed by other proxies at various sites, and the 8,200 years BP event was not apparent. These differences between records were probably due to the dominance of Corynocera ambigua, with percentages reaching $60 \%$ in parts of the Egelsee sequence. This taxon was not present in any of the 103 lakes used for the transfer function and its absence may have yielded less accurate inferences. Its presence in samples only associated with cold inferences at Egelsee suggests that this taxon is a cold indicator. However, it was also found in warm Danish lakes and the factors that determine the presence of $C$. ambigua remain unexplained. Most samples had a poor fit to temperature and instead, dissolved organic carbon seemed to be a factor influencing the chironomid assemblages during the Holocene. These results illustrate the need to better understand the ecology of chironomids and to disentangle the various factors that affect chironomid communities through time. Ultimately, such information will lead to more accurate temperature reconstructions.

Keywords Temperature reconstruction ·

Chironomid-inferred temperature ·

Swiss training set $\cdot$ Ecology of Corynocera ambigua 


\section{Introduction}

Chironomids (Insecta: Diptera) are widely distributed aquatic insects. While the adult stage is a terrestrial winged insect, the larvae develop in or on the surface of different substrates (sediments, plants, dead wood, other invertebrates) in aquatic, humid or semi-terrestrial environments (e.g. lakes, ponds, rivers, estuaries, bogs, marshes). In lake sediments, the chitinous $\left(\mathrm{C}_{6} \mathrm{H}_{12} \mathrm{O}_{5} \mathrm{~N}\right)$ head capsules of chironomid larvae preserve well and can be identified to genus, even to species level in certain cases, making it possible to characterize past assemblages. Subfossil chironomid assemblages have been used both qualitatively and quantitatively to infer various limnological variables such as trophic status (Lotter et al. 1998), oxygen concentration (Quinlan and Smol 2002), salinity (Heinrichs et al. 2001), lake depth (Korhola et al. 2000), acidification (Schnell and Willasen 1996), chlorophyll $a$ (Brodersen and Lindegaard 1999a) and especially air temperature (e.g. Heiri et al. 2003a, 2007b; Larocque et al. 2001, 2006) and water temperature (e.g. Walker et al. 1997).

Chironomids have been successfully used to reconstruct major and minor climatic oscillations during the Late Glacial period in the UK (Bedford et al. 2004), Germany (Hofmann 1983a), France (Heiri and Millet 2005), Italy (Heiri et al. 2007a; Lami et al. 1997; Larocque and Finsinger 2008), the Swiss Alps (Brooks 2000; Hofmann 1983b, 2001; Ilyashuk et al. 2009), Norway (Brooks and Birks 2000a) and The Netherlands (Heiri et al. 2007b). During the Holocene, a decrease of temperature through time in the high to mid northern latitudes was inferred using chironomids, with maximum temperature in the early Holocene in Siberia (Porinchu and Cwynar 2002), western Canada (Palmer et al. 2002), Iceland (Caseldine et al. 2003, 2006), Bulgaria (Stefanova et al. 2003) and Sweden (Larocque and Hall 2004), consistent with decreases observed from analysis of other temperature proxies (e.g. Koç et al. 1993; Bradley 2000). Chironomid analysis provided evidence of phases of cooler European summers during the Holocene in Switzerland, including a decrease of temperature dated to ca. 8,000 calibrated radiocarbon years BP (years BP; Heiri et al. 2003b). An event with similar timing was also recorded by chironomids at many sites in northern Sweden (Rosén et al. 2001) and in Finland (Korhola et al. 2002).
Good relationships were found between chironomidinferred temperatures and meteorological data (Larocque and Hall 2003; Larocque et al. 2009) indicating the potential of chironomids for accurate temperature reconstructions. Unfortunately, the method can also provide problematic reconstructions (e.g. Kurek et al. 2004; Velle et al. 2005b) probably due to the influence of factors other than climate affecting the chironomid community (e.g. human disturbance, Heiri and Lotter 2005; pH changes, Velle et al. 2005b; Dalton et al. 2005) or limits of the transfer function method (Heinrichs et al. 2004). Here, we describe a temperature reconstruction using chironomids preserved in the sediment of Egelsee, Switzerland. Egelsee is a raised bog and was first chosen for its location in the montane belt (800-1,200 m a.s.l) of Central Switzerland where there is little archeological evidence of human settlement (Aerni 1991). A recent pollen and macrofossil diagram from this site (Wehrli et al. 2007) indicated vegetation changes through the Late Glacial and the Holocene, which might be attributed to climate. To better understand the link between climate and vegetation in this part of Switzerland where few other records are available, a temperature reconstruction using chironomids was undertaken. This temperature reconstruction is compared with existing records in other regions of Switzerland and Europe to evaluate its reliability.

\section{Study site}

In its present state, Egelsee is a raised bog located $1 \mathrm{~km}$ northwest of Menzingen (Kanton $\mathrm{Zug}$ ) in Central Switzerland $\left(47^{\circ} 11^{\prime} \mathrm{N} / 8^{\circ} 35^{\prime} \mathrm{E}\right.$; Fig. 1). It lies at an elevation of $770 \mathrm{~m}$ a.s.l. and has a surface area of $12,000 \mathrm{~m}^{2}$ (Staubli 1998). The peat thickness is $140 \mathrm{~cm}$, representing the last ca. 800 years. Under this peat lies gyttja-type sediment which indicates that the site was previously a lake. The former lake had a catchment of 90,000 $\mathrm{m}^{2}$ (Staubli 1998).

The bog lies at the borderline between the Tertiary Molasse basin of the Swiss Plateau and the Prealps. On top of the Tertiary Molasse lies Quaternary till material deposited during several glacial and interglacial periods. The present relief shows many moraine hills and drumlins in this area. Numerous small lakes and ponds such as Egelsee originated in 


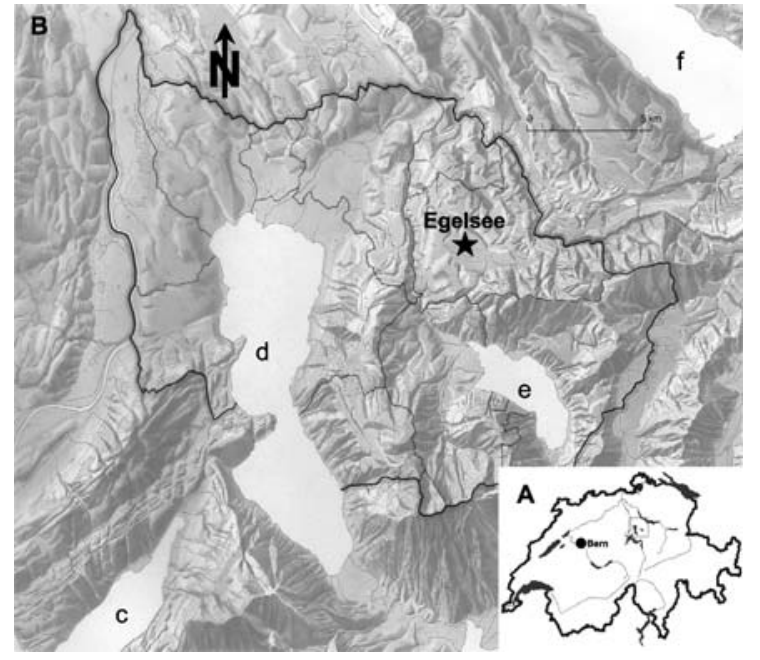

Fig. 1 A Location of Egelsee (770 m a.s.1.) in Switzerland. B Lakes surrounding Egelsee: $d$ is Lake Zug (410 $\mathrm{m}$ a.s.1.), $e$ is Lake Ägeri (720 m a.s.l) and $f$ is Lake Zürich (410 m a.s.1.)

depressions between these moraine hills after the retreat of the glaciers (Hantke 1992; Wyssling and Eikenberg 2000).

Data from two nearby climate stations [Wädenswil (463 $\mathrm{m}$ a.s.1.; $9 \mathrm{~km}$ northeast from Egelsee) and Einsiedeln (910 m a.s.1.; $13 \mathrm{~km}$ east-southeast from Egelsee)] were used to describe the present climate at Egelsee. The present-day annual precipitation is estimated at 1,350-1,750 mm. Mean annual, July, August and January temperatures are 7, 16, 13, and $-2.0^{\circ} \mathrm{C}$, respectively (norm values, 1961-1990, data source Meteo Schweiz www.meteoschweiz.ch). The coldest as well as the driest months are December, January and February and the warmest as well as the wettest months are June, July and August.

Egelsee is in a region of intensive agriculture. The north slope of Höhronen is covered by a forest dominated by Abies alba (Mill.), Fagus silvatica (L.), Pinus silvestris (L.) and individual stands of Acer pseudoplatanus (L.), and Sorbus aucuparia (L.) trees or shrubs. In spite of its small area, Egelsee shows many different wetland plant communities (Staubli 1998). Sphagnum bog vegetation, tall sedge community and acid small sedge community, transition raised bog/fen vegetation, purple moor grass meadow, and Sphagnum-Pinus forests are all present. Important plant taxa are Betula pendula (Roth.), Betula pubescens (Ehrh.), Comarum palustre (L.), Drosera rotundifolia (L.), Drosera obovata (Mert.), Frangula alnus
(Mill.), Menyanthes trifoliata (L.), Molinia caerulea (L.), Pinus mugo (Turra), Rhamnus sp., Rhynchospora alba (L.), and Scheuchzeria palustris (L.) (Staubli 1998).

\section{Materials and methods}

\section{Sampling}

The depth of the soft peat and gyttja deposits at Egelsee was surveyed with a corer on a grid of 25 by $25 \mathrm{~m}$. The maximum depth was 12.8 meters (Staubli 1998). In September 1998 two 12-m-long cores (8 cm diameter) were recovered from Egelsee using a modified Livingstone piston corer at the deepest part of the raised bog. The two cores, EGL 1 and EGL 2, were stored at $4^{\circ} \mathrm{C}$ prior to analysis.

\section{Chironomid analysis}

Since the goal of this study was to produce a temperature reconstruction, most samples analysed (83 samples) were within the gyttja-type sediment. To see how the chironomid assemblages changed at the interface between lacustrine sediment and peat and how the transition could affect the temperature reconstruction, a few samples (3) were analysed from the peat section.

About $4 \mathrm{~cm}^{3}$ of wet sediment were deflocculated using $\mathrm{KOH} 10 \%$ overnight and sieved with a $90 \mu \mathrm{m}$ mesh. Head capsules were hand picked under a stereomicroscope and mounted in Hydro-Matrix ${ }^{\odot}$. At least 50 head capsules were mounted. This number has been shown to give reliable temperature estimates (Heiri and Lotter 2001; Larocque 2001). The identification of head capsules was based on Wiederholm (1983), Oliver and Roussel (1983) and an identification guide by Larocque and Rolland (2006). The Tanytarsini were identified using Brooks et al. (2007). "Tanytarsus with spur" refers to Tanytarsini head capsules with a spur on the antennal pedestal; "Tanytarsus without spur" indicates Tanytarsini without a spur on the antennal pedestal and "Tanytarsini sp." relates to Tanytarsini head capsules without any antennal pedestal preserved. The key of Rieradevall and Brooks (2001) was used for Tanypodinae. Dicrotendipes II refers to Fig. 10.18 in Wiederholm (1983), Glyptotendipes II refers to 
Fig. 10.20 in Wiederholm (1983), Polypedilum IIIC refers to Fig. 10.61 type C in Wiederholm (1983), Cricotopus 285 and Cricotopus 289 refer to Figs. 285 and 289, respectively, in Oliver and Roussel (1983), Cricotopus B includes Cricotopus/Orthocladius head capsules with only a slightly reduced second lateral mentum tooth as described, e.g. for Cricotopus cylindraceus-type or Orthocladius oliveri-type in Brooks et al. (2007).

\section{Statistical analysis}

The chironomid diagram was drawn using C2 (Juggins 2003). Zonation methods followed the recommendations of Birks and Gordon (1985) and Bennett (1996). Numerical zonation was carried out by optimal partitioning using sum of squares criteria [programs TRAN (Version 1.41) and ZONE (Version 1.2; Juggins 1991)] and the number of statistically significant zone limits was determined with the broken-stick model (software BSTICK version 1.0, Bennett 1996).

The fossil assemblages were added passively to a canonical correspondence analysis (CCA) of the training set to determine the direction of change through time and the influence of the environmental variables on the fossil chironomid assemblages.

\section{Dating}

Twenty-nine samples of terrestrial plant macrofossils (needles, leaves, fruits, twigs, wood, and pieces of cones) from the core EGL1 of raised bog Egelsee were radiocarbon-dated by AMS (accelerator mass spectrometry) techniques at the Angström Laboratory, University of Uppsala. The ${ }^{14} \mathrm{C}$ results were calibrated with the program OxCal v3.5 (Stuiver et al. 1998; Ramsey 1995). The depth-age model was developed following methods described in Wehrli et al. (2007).

Training set and temperature reconstruction

A Swiss training set (TS) of 103 lakes (Heiri et al. 2007b; Heiri and Lotter 2005; Bigler et al. 2006) was used to reconstruct the mean July air temperature at Egelsee. The July air temperature gradient of this data set covered $5.0-18.4^{\circ} \mathrm{C}$, included chironomid assemblages covering an altitude of 420-2,815 m a.s.1., and lakes ranging in depth from 2.2 to $49.0 \mathrm{~m}$. The transfer function (TF) was developed using weighted averaging partial least squares (WAPLS) regression with two components and yielded a coefficient of determination $\left(r^{2}\right)$ of 0.87 and a root mean square error of prediction (RMSEP) of $1.46^{\circ} \mathrm{C}$ (evaluated using leave-one-out cross-validation).

To provide an indication of how well a fossil assemblage was represented in the modern calibration set, we calculated the proportion of taxa from each fossil assemblage represented in the modern calibration set (Birks 1998). When the proportion was lower than $60 \%$, we defined the fossil sample as being not satisfactorily represented in the training set. Canonical correspondence analysis (CCA) of the modern and the fossil data was carried out with the environmental variable of interest (e.g. July temperature) as the sole constraining variable to assess the fit of the fossil assemblages to the environmental variable of interest (Birks et al. 1990). We used the residual distance (square residual length, SqRL) of the modern samples as a criterion of fit: any fossil sample with a residual distance equal to or larger than the residual distance of the extreme $10 \%$ of the calibration set samples was considered to have a 'poor' fit to the environmental variable (Birks et al. 1990). A cut level of the 5th percentile of all chi-square distances within the modern data was used to define fossil samples with no 'good' modern analogue.

\section{Results and interpretation}

Sediment characteristics

Major changes occurred in the sediment composition of the 12-m EGL-1 core. The uppermost $100 \mathrm{~cm}$ consisted of carr peat. Between 100 and $122 \mathrm{~cm}$, the core contained gyttja. Between 123 and $140 \mathrm{~cm}$ the core consisted of moss peat. Between 140 and $1,152 \mathrm{~cm}$, deposits again consisted of gyttja; and the sediment between 1,152 and 1,199 cm consisted of minerogenic, more or less sandy/silty material. Of the 86 samples analysed for chironomids, 83 were in the gyttja and sandy/silty material.

Core chronology

Twenty-nine terrestrial plant macrofossils were radiocarbon-dated by AMS techniques from samples between 164 and $1,172 \mathrm{~cm}$ (Table 1). None of the 


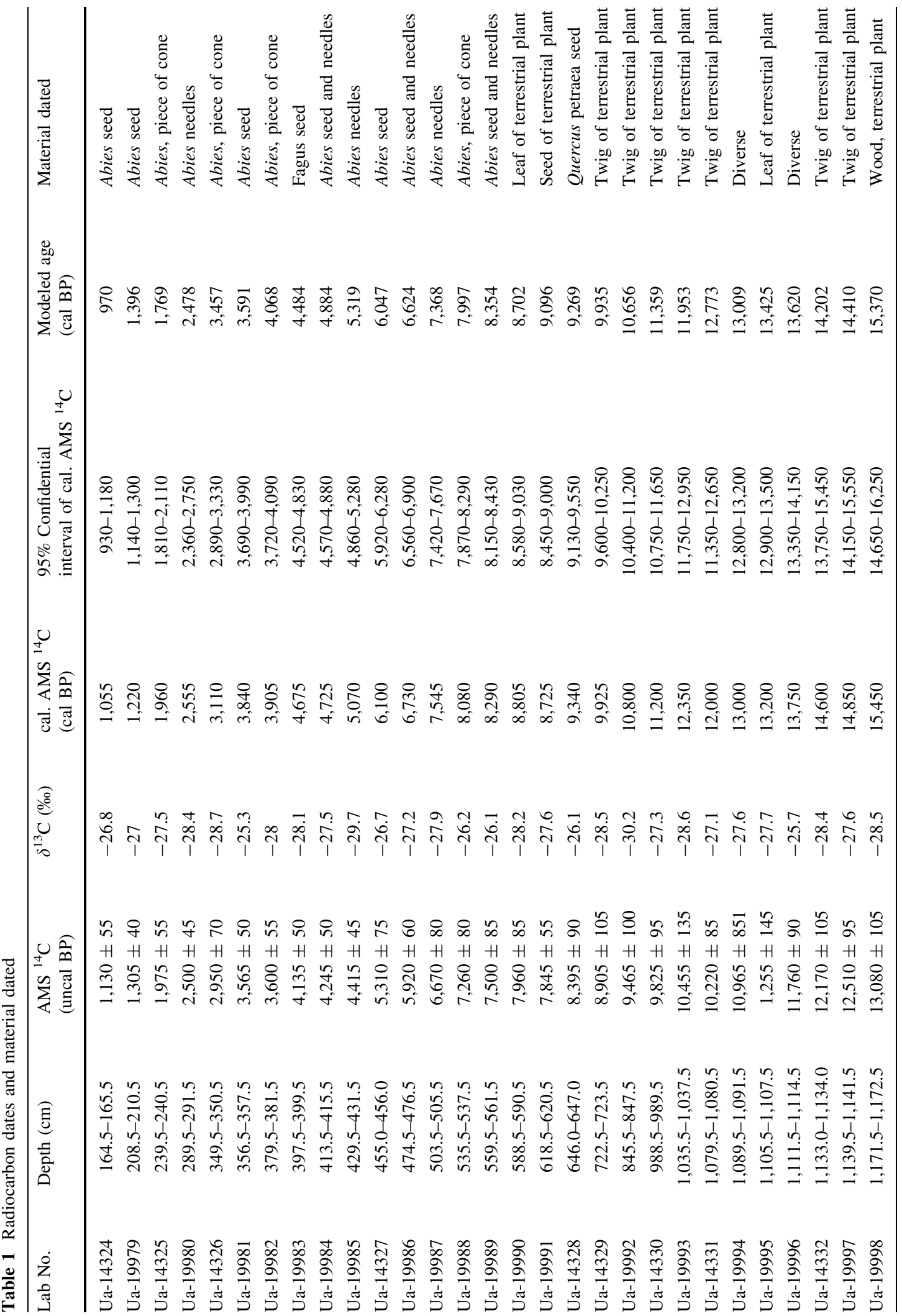


dates had to be rejected and no reversals were apparent in the depth-age relationship. Therefore the depth-age model (Fig. 2) had a high precision as reflected by the narrow $95 \%$ age confidence intervals of the model. The core extended back to ca. 16,200 calibrated ${ }^{14} \mathrm{C}$ years BP (cal BP). The sedimentation rate in the uppermost $100 \mathrm{~cm}$ was $1.8 \mathrm{~mm}$ per year, between 100 and $123 \mathrm{~cm}$ it was $1.6 \mathrm{~mm}$ per year, $1.5 \mathrm{~mm} /$ year between 122 and $140 \mathrm{~cm}, 0.7 \mathrm{~mm} /$ year between 140 and $1,152 \mathrm{~cm}$, and the sedimentation rate was $0.3 \mathrm{~mm} /$ year between 1,152 and $1,199 \mathrm{~cm}$.

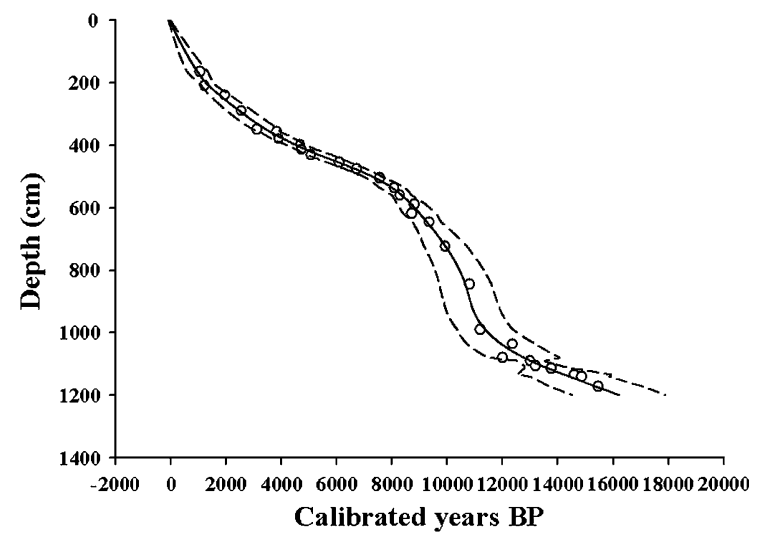

Fig. 2 Age-depth model. The open circles are the 29 calibrated ${ }^{14} \mathrm{C}$ dates. The line is the age-depth model and the dotted lines are the $95 \%$ age confidence intervals
Chironomids

Seventy-eight taxa were recorded in the 86 samples analysed. The distribution of the most abundant taxa is presented in Fig. 3. Nine significant zones were established using the ZONE program. Zones 1-6 seemed to be largely characterized by changes in the abundance of $C$. ambigua. While $C$. ambigua has been described as a cold-stenotherm taxon, and its temperature optima in various TSs varied between 6 and $12^{\circ} \mathrm{C}$ (e.g. Larocque et al. 2006; Barley et al. 2006), its presence in warm Danish lakes $\left(20^{\circ} \mathrm{C}\right)$ suggested that its distribution may be strongly affected by variables other than temperature (Brodersen and Lindegaard 1999b). Two methods of regrouping taxa into the category of cold-indicating chironomids [based on temperature optima $<10^{\circ} \mathrm{C}$ from various TSs (Brooks and Birks 2000a; Olander et al. 1999; Heiri et al. 2003a; Larocque et al. 2001, 2006)] were therefore used in Fig. 4: one including C. ambigua as a coldindicating taxon ("Cold with $C$. ambigua") and one excluding C. ambigua ("Cold without C. ambigua"). Zones 1, 2, 4 and 6 can be characterized as cold episodes. During zones 1 and 2, 40-80\% of the assemblages were composed of cold taxa such as Stictochironomus, Sergentia coracina, and Corynocera oliveri-type (without taking C. ambigua into

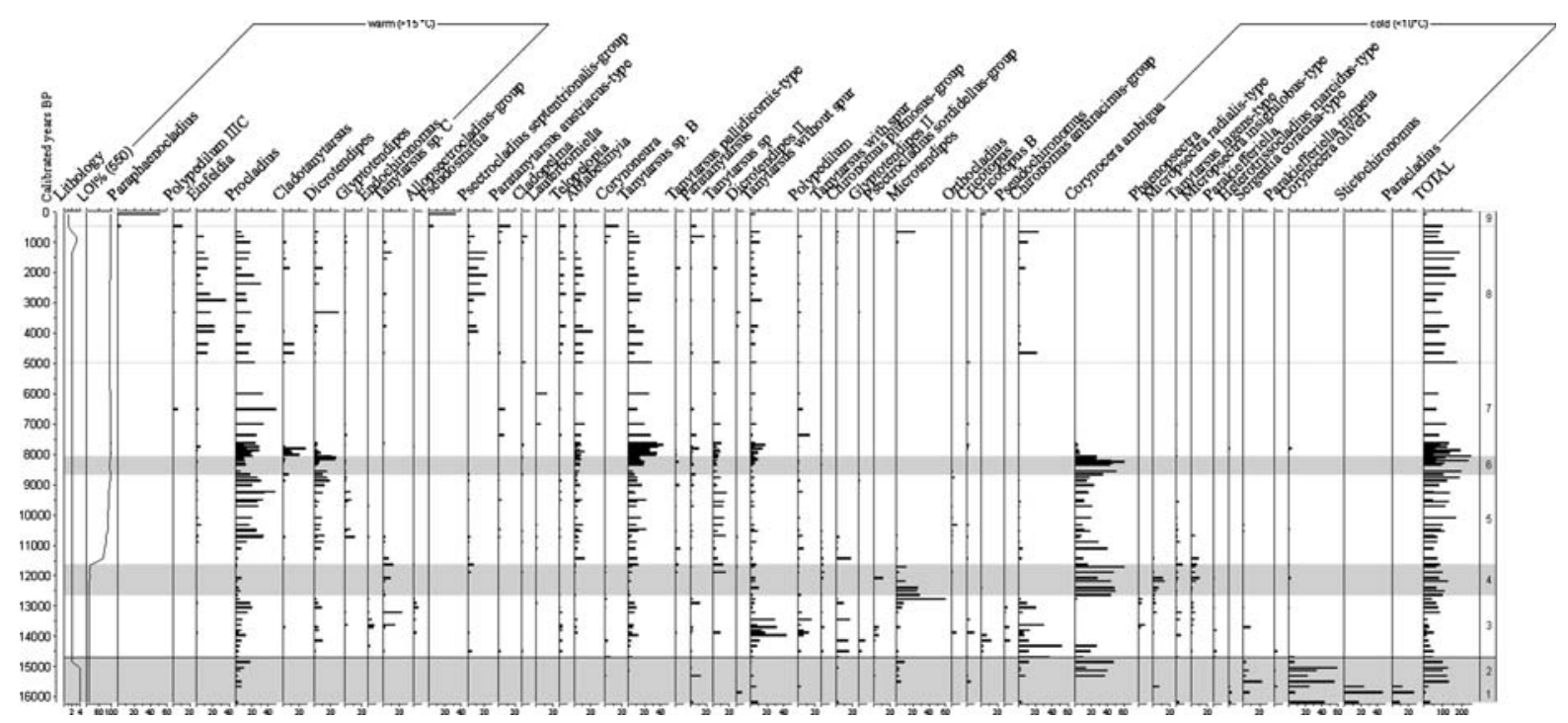

Fig. 3 Chironomid stratigraphy from Egelsee. The $y$-axis indicates the age in calibrated years BP. The percentages of each taxon are presented. Taxa were grouped according to their optima in many training sets. TOTAL is the number of head capsules per sample. The zones were defined using the ZONE program (Juggins 1991). The shaded zones are inferred cold episodes 


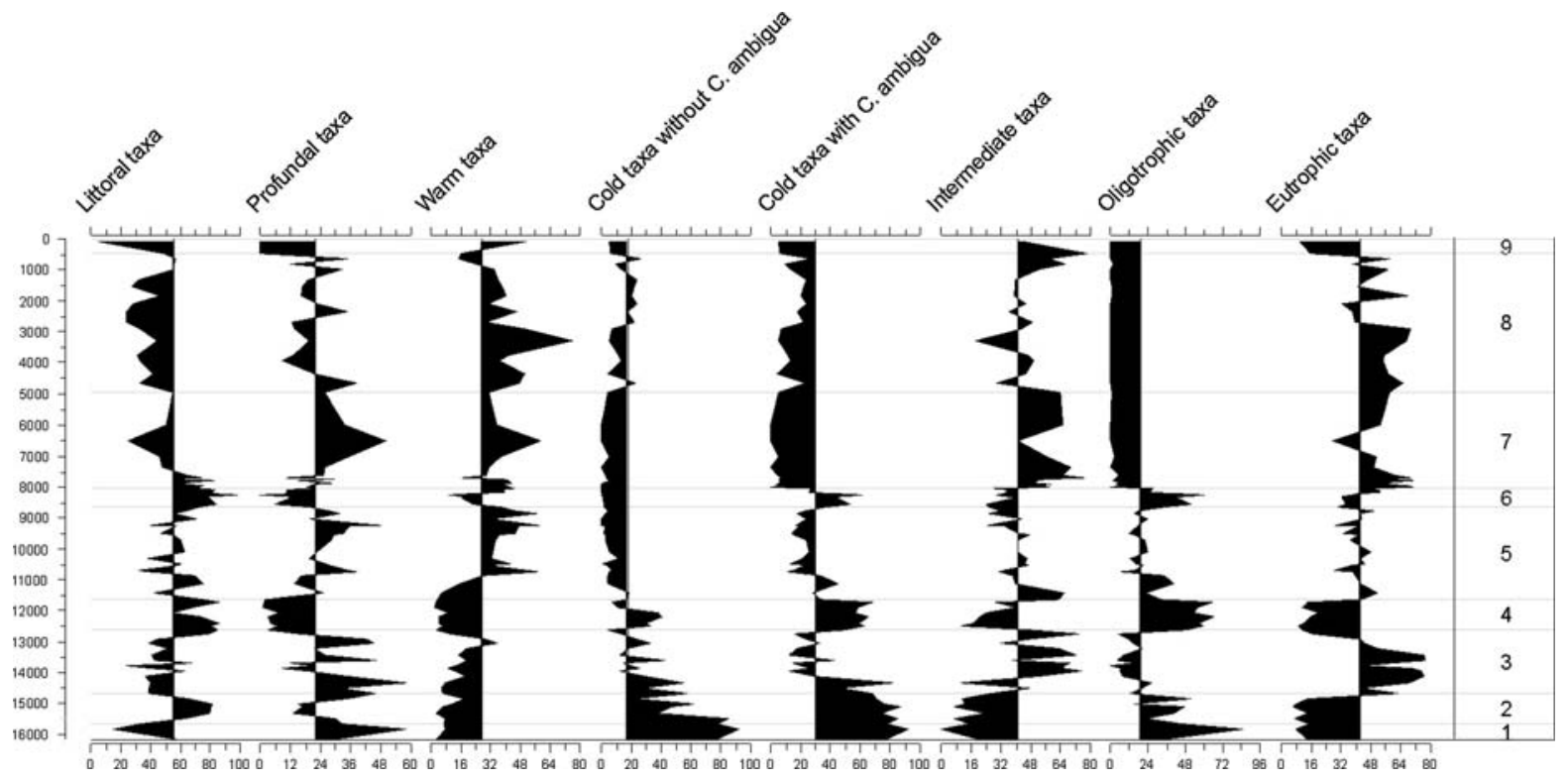

Fig. 4 Sums of chironomid percentages divided by categories: littoral (shallow-water), profundal (deep-water), warm (optimum $>15^{\circ} \mathrm{C}$ ), cold (optimum $<10^{\circ} \mathrm{C}$ ) (with Corynocera ambigua), cold (without Corynocera ambigua), intermediate

consideration) and less than $10 \%$ were taxa restricted to warmer temperatures. Abundances of taxa indicative of warm $\left(>15^{\circ} \mathrm{C}\right)$ and intermediate temperatures were below average. During zone $4,40 \%$ of the assemblages were cold-indicating taxa (without taking C. ambigua into consideration) and warm- and intermediate-indicating taxa were below average. In this zone, Microtendipes type II is the other co-dominant taxon and is considered typical of intermediate temperatures (Larocque et al. 2006). During zone 6, the percentages of taxa representative of warm and intermediate temperatures were below average again, but the only potentially cold-indicating taxon was C. ambigua. This zone could thus be described as a cold episode only if we consider C. ambigua as a taxon restricted to cool temperatures (see "Discussion").

The zone boundaries did not coincide with lithological changes, except for the first samples in the carr peat layer (Fig. 3). The chironomid assemblages did not seem to be influenced by the lithologic transitions (gyttja/peat/gyttja). These results suggest that, at Egelsee, changes in lithology did not have a major influence on chironomid assemblages.

Interestingly, there was no increase in percentages of littoral taxa or decrease in profundal taxa towards (optimum $10-15^{\circ} \mathrm{C}$ ), oligotrophic, and eutrophic taxa. The vertical lines are the average of the percentages for each category

the top of the core (Fig. 4) as we would expect with the infilling of the lake. Littoral taxa dominated during the cold episodes, mainly due to the abundance of $C$. ambigua, a shallow lake taxon. In the top samples, two chironomid taxa known to colonize shallow water and semi-terrestrial habitats [Pseudosmittia, Paraphaenocladius (Wiederholm 1983)] dominated the assemblages.

Changes in trophic state seemed to be related to the presence/absence of Corynocera ambigua in this core (Fig. 4); when C. ambigua increased, the percentages of oligotrophic taxa increased as well (after C. ambigua was removed from the analysis) and when $C$. ambigua decreased/disappeared, the abundance of eutrophic taxa increased. Eutrophic taxa increased and dominated the assemblages since 8,000 cal BP.

\section{Loss on ignition}

Loss on ignition (LOI) percentages were 25-30\% during the first four zones and they subsequently increased to $>90 \%$ in the last five zones (Fig. 3). The LOI changes were not associated with the appearance/disappearance of $C$. ambigua since the taxon 
was present in samples from ca. $20 \%$ up to $90 \%$ LOI values. In zones $1-4$, both warm and cold episodes were associated with lower LOI values. Similarly, in zones 5-9, higher LOI percentages were also associated with episodes dominated by both warm- and cold-indicating chironomids. These results suggest that LOI changes were not driving the chironomid assemblage changes at Egelsee.

\section{Temperature reconstruction (Fig. 5)}

Almost all of the inferences were colder than the mean July air temperature presently registered at Egelsee $\left(16^{\circ} \mathrm{C}\right)$. During the Oldest Dryas ( $>\sim 14,700$ cal BP), the chironomids yielded inferences for cold temperatures, with an average of ca. $11.4^{\circ} \mathrm{C}$. Temperatures colder by $8^{\circ} \mathrm{C}$ than today's temperatures were inferred in the first two samples. The temperature increased up to $17^{\circ} \mathrm{C}$, almost $1{ }^{\circ} \mathrm{C}$ warmer than present-day temperature, during the Bølling ( 14,700-14,000 cal BP) and decreased to about $15.5^{\circ} \mathrm{C}$ at the end of the Allerød $(\sim 14,000$ $12,700 \mathrm{cal}$ BP $)$. During the Younger Dryas ( $12,700-11,700$ cal BP), the average temperature was $13.9,2^{\circ} \mathrm{C}$ colder than today's temperature. During the early Holocene until ca. 8,300 cal BP, the inferred mean July air temperatures were, on average, around $15.3^{\circ} \mathrm{C}$. At about $7,900 \mathrm{cal} \mathrm{BP}$, the temperature decreased to ca. $14,2^{\circ} \mathrm{C}$ colder than the present-day temperature at Egelsee. This small decrease was for a short period of time since the temperature increased to ca. $16.5^{\circ} \mathrm{C}$ at ca. $7,600 \mathrm{cal}$ BP. The inferred temperatures were (on average) similar to present-day temperature until ca. 4,900 cal BP. After 4,900 cal BP, the chironomid-inferred temperatures were on average $\sim 14.2^{\circ} \mathrm{C}$.

\section{Applicability of the transfer function}

Corynocera ambigua was an abundant taxon in the fossil samples (Fig. 3), but was not present in any of the 103 lakes of the TS, leading to inferences based on assemblages with less than $60 \%$ of the fossil taxa represented in the modern dataset (Fig. 5b). Situations of "no-good-modern analogues" were numerous (Fig. 5a) and were found in samples with high abundances of $C$. ambigua. Forty-two percent of the samples had poor fit to temperature.
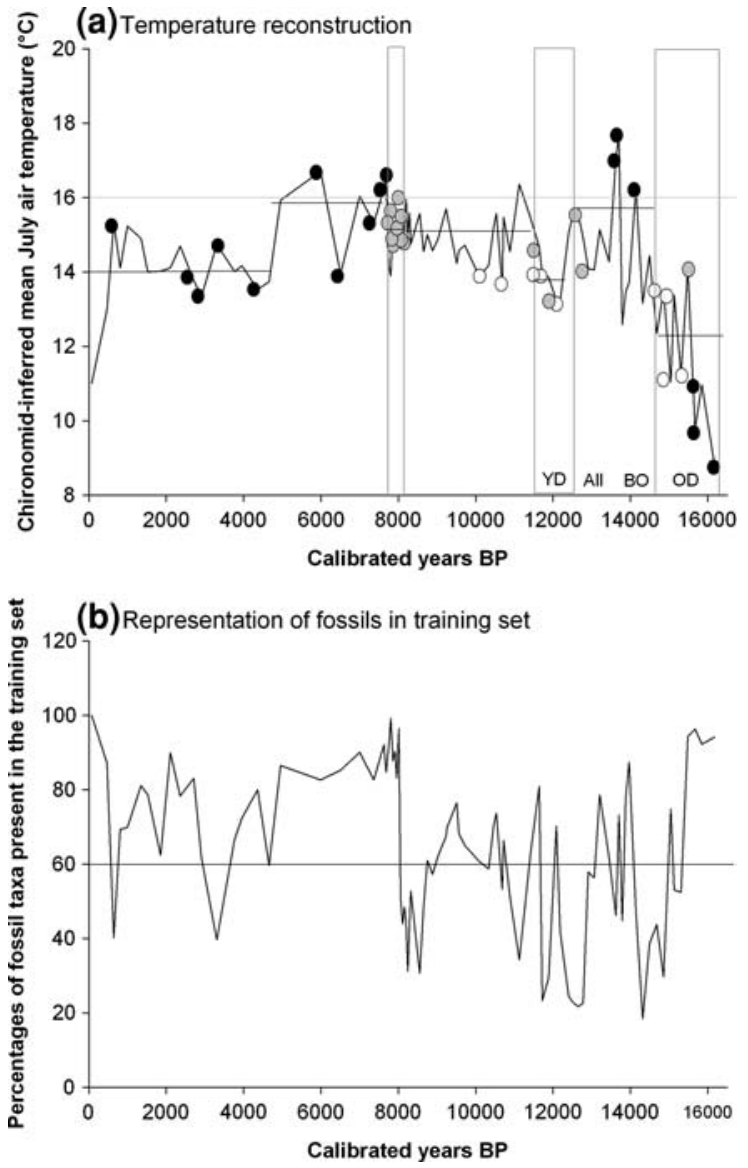

Fig. 5 a Temperature reconstruction using chironomids preserved in the sediment of Egelsee. The boxes represent the cold periods identified in the chironomid stratigraphy. The vertical gray line is the present-day temperature at Egelsee $\left(16^{\circ} \mathrm{C}\right)$ and the vertical black lines are the averages of inferred temperatures for the different sections of the record. The black circles represent samples with poor fit to temperature, the empty circles represent samples with no modern analogue and the gray circles represent samples with no modern analogue and poor fit to temperature. b Percentages of fossil assemblages present in the 103 lakes of the training set used to produce the chironomid-temperature inference model. The vertical line at $60 \%$ represents the limit of samples considered as having no modern analogue based on the poor representation of the taxa in the transfer function

Relationships between changes in chironomid assemblages and temperature

Figure 6 indicates the directional change of assemblages through time when the fossil samples were added passively in a CCA of the modern chironomid assemblages of the training set and selected environmental variables. Changes of the first Late Glacial 

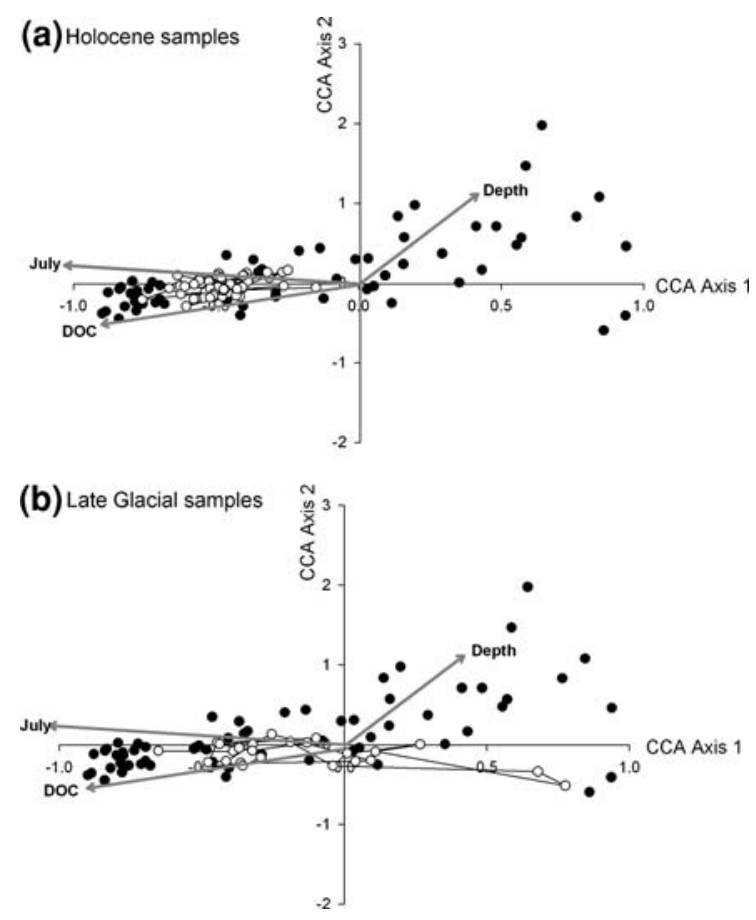

Fig. 6 Trajectory changes through time of fossil samples (empty circles) in the Egelsee record, passively plotted in a CCA of the training set lakes (black circles). The arrows indicate the direction of the parameters influencing the chironomid assemblages

samples followed the temperature gradient, but it was impossible to distinguish between the two driving forces at play, temperature and dissolved organic carbon concentrations (DOC) of the lake water, since these were both highly correlated in the modern TS (see e.g. Bigler et al. 2006).

\section{Discussion}

Faunistic changes and climate

Faunistic changes in the chironomid assemblages at Egelsee suggested that two cold periods occurred through the Late Glacial record, and possibly a third between 8,200-8,000 cal BP. The first period (zones 1 and 2 in the diagram), corresponding to the Oldest Dryas (16,000-14,800 cal BP) was dominated by cold stenotherms (Paracladius, Stictochironomus, Sergentia coracina-type, Parakiefferiella triquetra, Micropsectra radialis-type, Corynocera oliveri, Heterotrissocladius marcidus-type, Tanytarsus lugens-type) and
C. ambigua. Similar faunistic assemblages were recorded for this period in various parts of Switzerland and in adjacent regions (Table 2). Pollen evidence from Egelsee (Wehrli et al. 2007) indicated that the vegetation was dominated by upland herbs (Artemisia, Cyperaceae, Poaceae) and shrubs (Juniperus), with very low percentages of trees. This vegetation type dominated over all Switzerland (Burga and Perret 1998), suggesting a cold climate with open vegetation (Table 2).

The cold-indicator chironomid taxa disappeared at about 14,800 cal BP and this change was associated with a decrease in Betula pollen, an increase in Pinus sylvestris and decrease/disappearance of upland herbs and Juniperus (Wehrli et al. 2007). The simultaneous changes in both pollen and chironomid assemblages suggest that they responded to the same factor, i.e. climate. Between 14,800 and 12,700 cal BP (Bølling and Allerød), Chironomus plumosus-group, Polypedilum, Tanytarsus sp. B, Tanytarsus sp. C, Tanytarsus without spur and Dicrotendipes percentages were relatively high. C. ambigua persisted several 100 years into the Bølling and then disappeared. Similar changes were recorded during the Late Glacial interstadial at Lac Lautrey, France (Heiri and Millet 2005) and at Lac Long Supérieur, France (Gandouin and Franquet 2002; Table 2). The chironomid assemblages were similar in some lakes of Switzerland during the Bølling and Allerød, but different in others (Table 2). However, all assemblages were influenced by climatic fluctuations (Brooks 2000).

The second cold period suggested by the chironomid assemblages occurred during the Younger Dryas (12,700-11,700 cal BP). At Egelsee, assemblages were dominated by $C$. ambigua and by coldstenotherms such as Micropsectra radialis-type, Micropsectra insignilobus-type and Tanytarsus lugens-type. Microtendipes was also present. Similar taxa were recorded at Lac Lautrey (France) (Table 2). Cold indicators during the Younger Dryas were also recorded at Kråkenes, in Norway (Brooks and Birks 2000b), and in Switzerland (Brooks 2000; Heiri et al. 2003b; Table 2). The pollen record at Egelsee indicated a slight increase in Juniperus, Artemisia, Cyperaceae, Poaceae and in the sum of upland herbs (Wehrli et al. 2007), a signal typical of colder climate. At Gerzensee, on the Swiss Plateau, pollen-inferred temperatures were colder during the Younger Dryas (Lotter et al. 2000) and there was no 


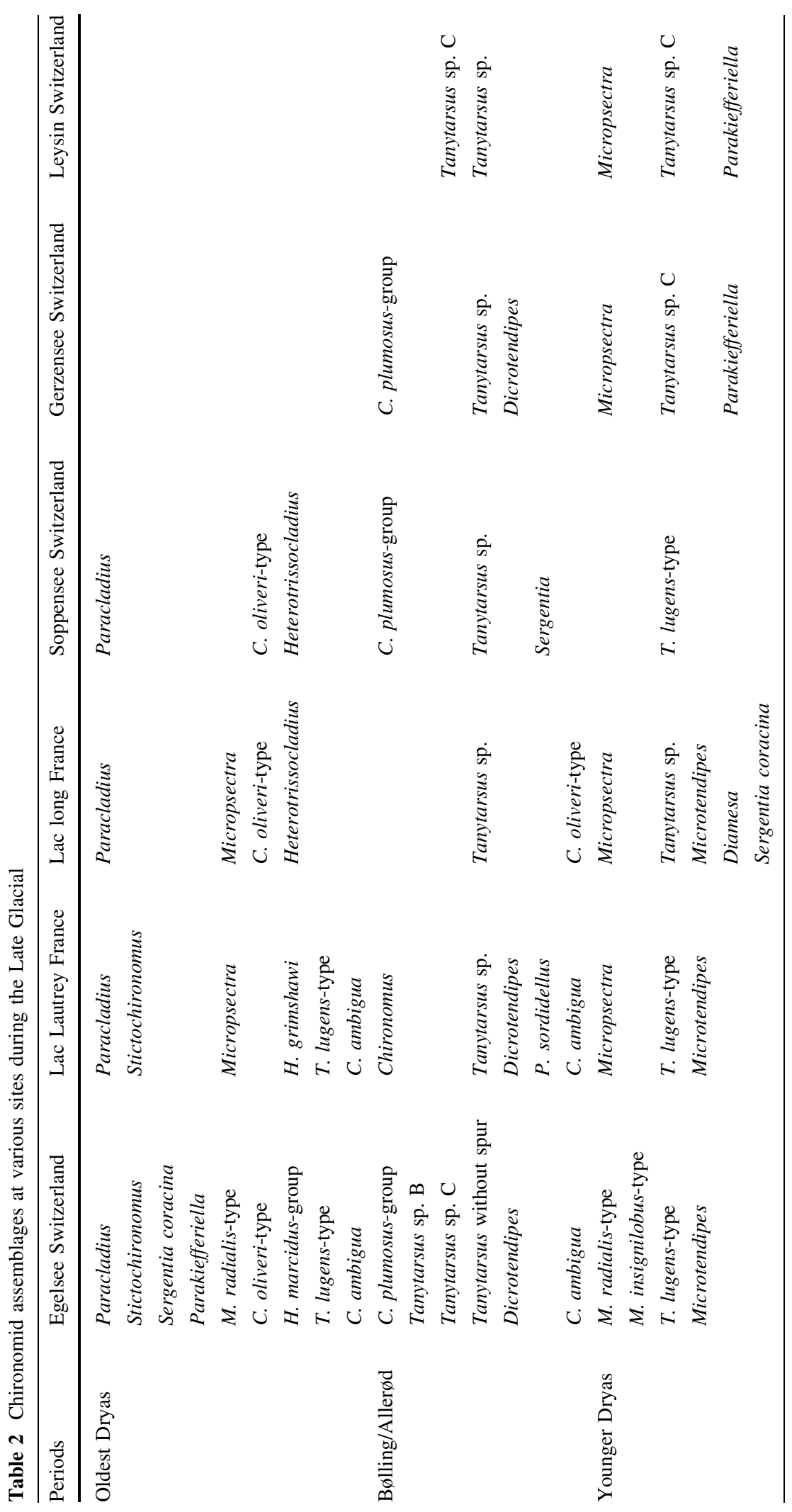


time-lag between changes in the pollen composition at Gerzensee and Leysin and the GRIP temperature record (Ammann et al. 2000). Glacier advances during the Younger Dryas period indicated colder climate at the Julier Pass in Switzerland (Ivy-Ochs et al. 1999).

At ca. 11,700 cal BP (transition Late Glacial/ Holocene), the Betula/Pinus forest near Egelsee changed to a Quercetum mixtum forest with taxa such as Acer, Ulmus, Tilia, Quercus robur, Alnus glutinosa, and Corylus (Wehrli et al. 2007). Simultaneously, warm stenotherms (Dicrotendipes, Glyptotendipes), and intermediate taxa (Ablabesmyia, Tanytarsus) increased and dominated in the chironomid assemblages, suggesting warmer climate. However, C. ambigua was still present although it decreased to about $20 \%$.

The possible third cold episode occurred between 8,500 and 8,000 years BP. This period is the most controversial in the record, since its description as a "cold episode" is mainly due to the dominance of C. ambigua, although all warm taxa described in the previous zone decreased and chironomids with a warm distribution represented less than $20 \%$ of the assemblages.

Corynocera ambigua a cold indicator?

Corynocera ambigua is, as its name suggests, an ambiguous taxon. It was considered a cold stenotherm (Lindberg 1970; Fjellberg 1972; Reiss and Germeister 1984; Walker 1990; Walker and MacDonald 1995) and its temperature optimum is low in some of the calibration datasets used for chironomidbased temperature reconstruction. For example, the temperature optimum of $C$. ambigua has been reported as $6^{\circ} \mathrm{C}$ (August air temperature) in eastern Canada (Larocque et al. 2006) and $10^{\circ} \mathrm{C}$ (July air temperature) in Sweden (Larocque et al. 2001). It was found mainly in lakes of cool to intermediate July air temperatures of $15-7^{\circ} \mathrm{C}$ in Finland (Olander et al. 1999) and in lakes above $60^{\circ} \mathrm{N}$ in western Canada (Barley et al. 2006). In the northwest North American TS, C. ambigua had a temperature optimum of $12.6^{\circ} \mathrm{C}$ (Barley et al. 2006). On Victoria Island, C. ambigua was found in 10 of the 30 sampled lakes, in temperatures between 6 and $14^{\circ} \mathrm{C}$ (Porinchu et al. 2009), and in Russia it was found in forested lakes (Porinchu and Cwynar 2000).
In fossil records, C. ambigua is often recorded during the coldest periods of the Late Glacial. For example, it has been found in assemblages deposited during the Late Glacial cold phases in Hawes Water, northwest England (Bedford et al. 2004) and during cold periods at a Norwegian site (Velle et al. 2005a). It was described as a temperate taxon in southeast Scotland (Brooks and Birks 2000b), but colder climate oscillations during the Interstadial were associated with increases in its abundance. At Lac Lautrey (France), C. ambigua was present only during the cold episodes of the Oldest and the Younger Dryas, and was in assemblages similar to those found at Egelsee (i.e. with Stictochironomus, Paracladius, and C. oliveri in the Oldest Dryas and with Microtendipes during the YD). Hofmann and Winn (2000) found $C$. ambigua only during the Younger Dryas in four cores in the Baltic region, also suggesting that the taxon is associated with colder climate. In Finland, Sarmaja-Korjonen et al. (2006) described the taxon as primarily found in newly formed lakes after deglaciation. Luoto et al. (2008) found that $C$. ambigua percentages increased during the coldest parts of the "Little Ice Age" and disappeared afterwards. However, recently the taxon was found in warm $\left(20^{\circ} \mathrm{C}\right)$ Danish lakes, bringing into question its classification as a "cold-stenotherm" (Brodersen and Lindegaard 1999b). Based on these studies, it is obvious that C. ambigua cannot be described as a true cold-stenotherm, although its presence during cold episodes in the past suggests that it thrived during these cold spells. Brodersen and Lindegaard (1999b) attributed higher abundance of C. ambigua to abundant oxygen availability, low nutrient content and extensive charophyte beds. Charophyte beds have been shown to increase with colder climate in at least some records (Jones et al. 1996). Oxygen availability is also often higher in colder climates (Liikanen et al. 2002). This suggests that there may be a possible indirect link between the presence of $C$. ambigua, charophyte beds, oxygen availability and colder climate, at least during the Late Glacial. The disappearance of the taxon at Egelsee after the 8,200 years BP event is also puzzling, since it is generally considered that the early and middle Holocene were characterized by very similar temperatures in Central Europe (e.g. Kofler et al. 2005). At Lac Lautrey, Magny et al. (2006) attributed the disappearance of C. ambigua to 
higher lake productivity, associated with increases in soil and tree production. Hofmann and Winn (2000) also attributed its presence to oligotrophic conditions and its disappearance might be related to increases in lake productivity/eutrophication. Similar results were obtained at Egelsee, the disappearance of C. ambigua corresponded with sharp decreases in oligotrophic taxa and increases in eutrophic taxa (Fig. 4). The vegetation history (Wehrli et al. 2007) indicated changes in the tree composition of local forests around 8,000 cal $\mathrm{BP}$, which were associated with changes in soil, and probably led to changes in the lake's productivity/trophic state. In periods when $C$. ambigua dominated, tree percentages decreased and abundances of shrubs increased.

\section{Temperature reconstruction}

Forty-five percent of the chironomid assemblages used to produce July air temperature estimates had either a poor fit to temperature, no modern analogues, or both. This result suggests that almost half the inferences are based on assemblages which are poorly represented in the modern calibration dataset and should therefore be interpreted with caution. The samples with no modern analogues were mainly those with high abundances of $C$. ambigua. Many of the Holocene samples had a poor fit with temperature and the CCA analysis with fossil samples added passively to the training set samples suggested that DOC might be the factor influencing the chironomid assemblages for the past 10,000 years.

\section{The Late Glacial}

The patterns of temperature change inferred from chironomids during the Late Glacial are quite similar to various multi-proxy reconstructions in Switzerland (e.g. Ilyashuk et al. 2009; Lotter et al. 2000) and Europe (e.g. Bedford et al. 2004; Heiri and Millet 2005; von Grafenstein et al. 1999), with cold climate recorded during the Oldest Dryas, a sharp increase registered at the beginning of the Bølling followed by a slow decrease in the Allerød, cold temperatures during the Younger Dryas, and an increase in temperature registered at the transition to the early Holocene. However, the amplitude of changes as recorded by chironomids at Egelsee was sometimes smaller than the amplitude recorded by other proxies.
During the Oldest Dryas (OD), the chironomidinferred temperatures were on average $11.4^{\circ} \mathrm{C}$. Temperatures in this range would suggest that Egelsee was partly surrounded by treeless environment during the Oldest Dryas. This is also suggested by the pollen record at this site (Wehrli et al. 2007) with pollen percentages dominated by upland herbs and very low percentages $(<20 \%)$ of tree pollen. At Lac Lautrey in France and at Lago di Lavarone in northern Italy, chironomids yielded temperature inferences in the range of $10-12^{\circ} \mathrm{C}$ (Heiri and Millet 2005; Heiri et al. 2007a). The similarity between the records suggests that the temperature inferred from chironomids at Egelsee was accurate.

The following increase of temperature was consistent with many records in Europe that were inferred from chironomids (Bedford et al. 2004; Heiri and Millet 2005), isotopes from ostracod shells (von Grafenstein et al. 1999), stable isotopes (Jones et al. 1996; O'Connell et al. 1999), oxygen-isotopes in marine cores (Ahlberg et al. 1996) and coleopteran remains (Lemdahl 2000). The amplitude of temperature change from the Oldest Dryas to the Bølling/ Allerød was in the range of $3-4^{\circ} \mathrm{C}$. This amplitude corresponded well to temperature changes of $3-4^{\circ} \mathrm{C}$ reconstructed from chironomids in northern Italy (Heiri et al. 2007a), and from chironomids at Lac Lautrey in France (Heiri and Millet 2005).

During the Younger Dryas, the decrease in chironomid-inferred temperature (compared to the Bølling/Allerød average) was in the range of $1.5^{\circ} \mathrm{C}$. Similar amplitudes $\left(1.5-2^{\circ} \mathrm{C}\right)$ were inferred from chironomids at Hinterburgsee (Switzerland, Heiri et al. 2003a) and at Lac Lautrey, Eastern France (Heiri and Millet 2005). However, the temperature decrease in the Younger Dryas compared to the Bølling/Allerød was on the order of $3^{\circ} \mathrm{C}$ at Hawes Water, northwest England (Bedford et al. 2004) and at Whitrig Bog, Scotland (Brooks and Birks 2000b). Several climatic reconstructions suggested a decrease of $3-4^{\circ} \mathrm{C}$ in mean annual air temperature (Eicher and Siegenthaler 1976; Eicher 1979, 1987; Lotter et al. 2000; von Grafenstein et al. 2000) during the Younger Dryas. Compared to present-day temperature, the temperature anomaly inferred from chironomids was $-2^{\circ} \mathrm{C}$. Using pollen and Cladocera, Lotter et al. (2000) inferred a summer temperature anomaly of -6.6 to $-7.6^{\circ} \mathrm{C}$ for the Younger Dryas in Switzerland while von Grafenstein et al. (1999) 
inferred a mean annual temperature anomaly in the range of $-6^{\circ} \mathrm{C}$ in Germany using ostracods. Mean annual temperatures were about $8^{\circ} \mathrm{C}$ colder than today in Europe, as estimated by permafrost distribution (Isarin 1998). Coleopteran assemblages over Britain yielded an estimated decrease of $7-8^{\circ} \mathrm{C}$ in the mean temperature of the warmest month during the Younger Dryas compared to today's temperature (Coope et al. 1998). These results suggest that the amplitude of temperature changes during the Younger Dryas might have been under-estimated using chironomids at Egelsee. If $C$. ambigua, with a temperature optimum varying from 4.3 to $12^{\circ} \mathrm{C}$ in different $\mathrm{Tfs}$, and percentages reaching $60 \%$ in the Younger Dryas, would have been included, the chironomid-inferred temperature during this period would have been considerably colder. The lower amplitude in temperature changes was probably due to the limits of the training set, as the inferences were based on chironomid assemblages representing only $40 \%$ of the fossil assemblages.

\section{The early Holocene}

Holocene temperature reconstructions based on chironomids are confounded by two major factors: (1) the climate change recorded is usually within the error of prediction of the applied chironomid-temperature inference models, and (2) climate was not always the dominant factor influencing the chironomid assemblages during the Holocene (Brooks 2006). At Egelsee, DOC may have influenced the changes in chironomid communities during the Holocene. The pattern of temperature changes was thus expected to be poorly related to other multi-proxy temperature records in the area.

In the early Holocene, glacier retreats were recorded in the Central Swiss Alps (Hormes et al. 2001) suggesting warmer climate. Mean annual temperatures in and around the Alps increased by ca. $3-6^{\circ} \mathrm{C}$ in the early Holocene (Eicher 1994; Schwander et al. 2000). At Egelsee, inferred July air temperature increased by $3^{\circ} \mathrm{C}$ (compared to the lowest inferred temperatures during the YD), but this increase was followed by a decrease of about $1{ }^{\circ} \mathrm{C}$ between 10,700 and 10,300 years BP. At Hinterburgsee (Heiri et al. 2003a), the temperature increase was of the same order $\left(3^{\circ} \mathrm{C}\right)$ and a decrease of about $0.8^{\circ} \mathrm{C}$ was inferred between ca. 10,700 and 10,500 years
BP. Although the registered decreases were within the error of prediction of the model, this event was recorded in other records in the Swiss and Austrian Alps (e.g. Patzelt 1977; Wick and Tinner 1997; Haas et al. 1998). In central Europe, the timing of this event was estimated between 10,750 and 10,200 years BP (Haas et al. 1998).

In the absence of higher early Holocene temperatures reconstructed based on chironomids at Sägistalsee (Heiri and Lotter 2003), the authors argued that factors other than climate were driving the chironomid assemblages during the early Holocene. At Egelsee, C. ambigua was still present in the early Holocene (with percentages reaching 20\%) and its presence suggests that the climate was possibly cold enough to support the taxon until ca. 8,000 cal BP, or that another factor had more influence on the chironomid community than climate. When the fossil chironomid assemblages were added passively to the CCA of the training set lakes, DOC was probably a factor affecting the assemblages in conjunction with July temperature. The factors affecting the chironomid communities must be disentangled to obtain a clear climate signal in the record of Egelsee.

\section{The 8,200 years BP event}

The 8,200 years BP event has been recorded in various sites in Europe (Heiri et al. 2004; Haas et al. 1998; Tinner and Lotter 2001; McDermott et al. 2001; Rosén et al. 2001; Korhola et al. 2000; von Grafenstein et al. 1999). The pollen stratigraphy at Egelsee indicated a sharp decrease of Corylus and the onset of Abies, which was thought to be caused by a decrease in temperature (Wehrli et al. 2007). A decrease in temperature of $2{ }^{\circ} \mathrm{C}$ compared to today's temperature was inferred at Egelsee between 7,900 and 7,600 cal. BP. At Hinterburgsee, a decrease in temperature $\left(1-2^{\circ} \mathrm{C}\right)$ was recorded between 8,300 and $7,700 \mathrm{cal}$ BP. At Egelsee, the assemblages were dominated (60\%) by C. ambigua between 8,500 and $8,200 \mathrm{cal}$ BP. The absence of this taxon, with generally colder optimum in the TS used for temperature reconstruction, might have prevented colder inferences from being obtained. The taxon was also dominant during the 8,200 cal BP event in some sites in Norway (Velle et al. 2005a). Based on chironomid assemblages in Egelsee, this period could only be considered as cold if $C$. ambigua is indeed a cold-stenotherm, which is 
not clear from its modern distribution in both cold arctic/subarctic lakes and warm Danish lakes. Based on its ecological preferences and the Egelsee record, the presence of $C$. ambigua at that time was probably due to more oligotrophic conditions, which were possibly caused by changes in tree and soil composition associated with climatic cooling.

\section{The late Holocene}

After 7,600 to ca. 5,000 cal. BP, a more or less stable climate was reconstructed from chironomids at Egelsee, and this stability was followed by a decrease in temperature to the late Holocene. A similar pattern was reconstructed at Sägistalsee, Bernese Alps (Heiri and Lotter 2003). At Hinterburgsee, another site in the Swiss Alps, temperatures after 5,000 years BP decreased, but increased once again during the last ca. 500 years (Heiri et al. 2003a). The surface samples at Egelsee were composed of no-modern analogues and were mainly terrestrial chironomid taxa. It is thus not surprising that the reconstructed modern temperature does not reflect the present-day temperature of $\sim 16^{\circ} \mathrm{C}$.

\section{Conclusions}

The Egelsee chironomid record provided a temperature reconstruction which captured the major temperature variations of the Late Glacial period and quantified some of the major temperature changes of the Holocene such as the Younger Dryas-Holocene transition and the Late Holocene cooling trend. However, two factors complicated the interpretation of the temperature reconstruction and may have influenced the reliability of the record. First, the transfer function method was complicated by the dominance of one taxon, C. ambigua, which, by its absence in the TF, led to a range of changes that were smaller than expected (YD) or absent $(8,200$ years BP event) in the reconstruction. Second, dissolved organic carbon (DOC) may have had a major impact on chironomid assemblages through time and possibly masked the climate signal, especially during the Holocene part of the record. The presence, and even dominance of $C$. ambigua in samples associated with cold climate was in agreement with a number of other Late Glacial temperature records, but failed to resolve the question of whether $C$. ambigua should be considered a cold indicator or not. Little is known about the ecology of this taxon. It is sometimes found in cold lakes and/or during cold periods in the past. On the other hand, it was found in warm $\left(>20^{\circ} \mathrm{C}\right)$ Danish lakes. At Egelsee, the major question remaining is whether C. ambigua responded to temperature change, or whether it was actually responding to changes in nutrient and/or oxygen regime. This study illustrates the limits of the transfer function method to reconstruct temperature in the absence of modern analogues and when samples have poor fit to temperature. It also demonstrates the necessity to cross-validate chironomid-based temperature records with other, independent palaeotemperature reconstructions where possible, especially if inferences are affected by non-analogue problems.

Acknowledgments Thanks to Lucien von Guten who mounted some of the chironomid samples. This research was possible with the help of NCCR and NSERC grants to I. Larocque.

Open Access This article is distributed under the terms of the Creative Commons Attribution Noncommercial License which permits any noncommercial use, distribution, and reproduction in any medium, provided the original author(s) and source are credited.

\section{References}

Aerni K (1991) Siedlungsprozesse an der Höhengrenze der Ökumene. Am Beispiel der Alpen. Referate der 16. In: Aerni K, Egli H-R, Fehn K (eds) Tagung des Arbeitskreises für genetische Siedlungsforschung in Mitteleuropa, vom 20. bis 23. September 1989 in Spiez. Bonn/ Bern, 219 pp

Ahlberg K, Almgern E, Wright HE Jr, Ito E, Hobbie S (1996) Oxygen-isotope record of Late Glacial climatic change in western Ireland. Boreas 25:257-267

Ammann B, Birks HJB, Brooks SJ, Eicher U, von Grafenstein U, Hofmann W, Lemdahl G, Schwander J, Tobolski K, Wick L (2000) Quantification of biotic responses to rapid climatic change around the Younger Dryas: a synthesis. Palaeogeogr Palaeoclimatol Palaeoecol 159:313-347

Barley EM, Walker IR, Kurek J, Cwynar LC, Mathewes RW, Gajewski K, Finney BP (2006) A northwest North American training set: distribution of freshwater midges in relation to air temperature and lake depth. J Paleolimnol 36:295-314

Bedford A, Jones RT, Lang B, Brooks S, Marshall JD (2004) A Late Glacial chironomid record from Hawes water, northwest England. J Quat Sci 19:281-290 
Bennett KD (1996) Determination of the number of zones in a biostratigraphical sequence. New Phytol 132:155-170

Bigler C, Heiri O, Krskova R, Lotter AF, Sturm M (2006) Distribution of diatoms, chironomids and cladocerans in surface sediments of thirty mountain lakes in south-eastern Switzerland. Aquat Sci 68:154-171

Birks HJB (1998) Numerical tools in paleolimnology-progress, potentialities, and problems. J Paleolimnol 20:307322

Birks HJB, Gordon AD (eds) (1985) Numerical methods in quaternary pollen analysis. Academic Press, London

Birks HJB, Line JM, Juggins S, Stevenson AC, ter Braak CJF (1990) Diatoms and $\mathrm{pH}$ reconstruction. Philos Trans R Soc B327:263-278

Bradley RS (2000) Past global changes and their significance for the future. Quat Sci Rev 19:391-402

Brodersen KP, Lindegaard C (1999a) Classification, assessment and trophic reconstruction of Danish lakes using chironomids. Freshw Biol 42:143-157

Brodersen KP, Lindegaard C (1999b) Mass occurrence and sporadic distribution of Corynocera ambigua Zettersedt (Diptera, Chironomidae) in Danish lakes. Neo and palaeolimnological records. J Paleolimnol 22:41-52

Brooks SJ (2000) Late Glacial fossil midge stratigraphies (Insecta: Diptera: Chironomidae) from the Swiss Alps. Paleogeogr Palaeoclimatol Palaeoecol 159:261-279

Brooks SJ (2006) Fossil midges (Diptera: Chironomidae) as palaeoclimatic indicators for the Eurasian region. Quat Sci Rev 25:1894-1910

Brooks SJ, Birks HJB (2000a) Chironomid-inferred Late Glacial and early-Holocene mean July air temperatures for Kråkenes Lake, western Norway. J Paleolimnol 23:77-89

Brooks SJ, Birks HJB (2000b) Chironomid-inferred Late Glacial air temperatures at Whitrig Bog, southeast Scotland. J Quat Sci 15:759-764

Brooks SJ, Langdon PG, Heiri O (2007) The identification and use of Palaearctic Chironomidae larvae in palaeoecology. QRA Technical Guide No. 10, Quaternary Research Association, $276 \mathrm{pp}$

Burga CA, Perret R (1998) Vegetation und Klima der Schweiz seit dem jüngeren Eiszeitalter. Ott Verlag, Thun

Caseldine C, Geirsdottir A, Langdon P (2003) Efstadalsvatn- a multi-proxy study of a Holocene lacustrine sequence from NW Iceland. J Paleolimnol 30:55-73

Caseldine C, Langdon P, Homes N (2006) Early Holocene climate variability and the timing and extent of the Holocene thermal maximum (HTM) in Northern Iceland. Quat Sci Rev 25:2314-2331

Coope GR, Lemdhal G, Lowe JJ, Walkling A (1998) Temperature gradients in northern Europe during the last glacial-Holocene transition (14-9 14C kyr BP) interpreted from coleopteran assemblages. J Quat Sci 13:419433

Dalton C, Birks HJB, Brooks SJ, Cameron NG, Evershed RP, Peglar SM, Scott JA, Thompson R (2005) A multi-proxy study of lake-development in response to catchment changes during the Holocene at Lochnagar, north-east Scotland. Paleogeogr Palaeoclimatol Palaeoecol 221:175201

Eicher U (1979) Die ${ }^{18} \mathrm{O} /{ }^{16} \mathrm{O}$ - und ${ }^{13} \mathrm{C} /{ }^{12} \mathrm{C}$-Isotopenverhältnisse in spätglazialen Süsswasserkarbonated und ihr Zussamenhang mit den Ergebnissen der Pollenanalyse. $\mathrm{PhD}$ thesis, University of Bern, Bern

Eicher U (1987) Die spätglazialen sowie die frühpostglazialen Klimaverhältnisse im Rereich der Alpen: sauerstoffisotopenkurven kalkhaltiger Sedimente. Geogr Helv 42:99-104

Eicher U (1994) Sauerstoffisotopenanalysen durchgeführt and spät-sowie frühpostglazialen Seekreiden. Diss Bot 234:277-286

Eicher U, Siegenthaler U (1976) Palynological and oxygen isotope investigation on Late Glacial sediment cores from Swiss lakes. Boreas 5:109-117

Fjellberg A (1972) Present and late Weichselian occurrence of Corynocera ambigua Zett (Dip. Chironomidae) in Norway. Nor Entomol Tidsskr 19:59-61

Gandouin E, Franquet E (2002) Late Glacial and Holocene chironomid assemblages in "Lac Long Inférieur" (southern France, $2090 \mathrm{~m}$ ): palaeoenvironmental and palaeoclimatic implications. J Paleolimnol 28:317-328

Haas JN, Richoz I, Tinner W, Wick L (1998) Synchronous Holocene climate oscillations recorded on the Swiss Plateau and at timberline in the Alps. Holocene 8:301309

Hantke R (1992) Eiszeitalter 3. Die jüngste Erdgeschichte der Schweiz und ihrer Nachbargebiete. Ott Verlag, Thun

Heinrichs ML, Walker IR, Mathewes RW (2001) Chironomidbased paleosalinity records in southern British Columbia, Canada: a comparison of transfer functions. J Paleolimnol 26:147-159

Heinrichs ML, Peglar SM, Bigler C, Birks HJB (2004) A multi-proxy palaeoecological study of Alanen Laanijärvi, a boreal-forest lake in Swedish Lapland. Boreas 34:192206

Heiri O, Lotter AF (2001) Effect of low count sums on quantitative environmental reconstructions: an example using subfossil chironomids. J Paleolimnol 26:343-350

Heiri O, Lotter AF (2003) 9000 years of chironomid assemblage dynamics in an Alpine lake: long-term trends, sensitivity to disturbance, and resilience of the fauna. J Paleolimnol 30:273-289

Heiri O, Lotter AF (2005) Summer temperature reconstruction in the Alps based on fossil assemblages of aquatic organisms: a review. Boreas 34:506-516

Heiri O, Millet L (2005) Reconstruction of Late Glacial summer temperatures from chironomid assemblages in Lac Lautrey (France). J Quat Sci 20:33-44

Heiri O, Lotter AF, Hausmann S, Kienast F (2003a) A chironomid-based Holocene summer air temperature reconstruction from the Swiss Alps. Holocene 13: 477-484

Heiri O, Wick L, van Leeuwen JFN, van der Knapp W, Lotter AF (2003b) Holocene tree immigration and the chironomid fauna of a small Swiss subalpine lake (Hinterbursee, $1515 \mathrm{~m}$ asl). Palaeogeogr Palaeoclimatol Palaeoecol 189:35-53

Heiri O, Tinner W, Lotter AF (2004) Evidence for cooler European summers during periods of changing meltwater flux to the North Atlantic. Proc Natl Acad Sci 101:1528515288

Heiri O, Filippi M-A, Lotter AF (2007a) Lateglacial summer temperature in the Trentino area (Northern Italy) as reconstructed by fossil chironomid assemblages in Lago 
di Lavarone (1100 m a.s.1.). Stud Trent Sci Nat Acta Geol 82:299-308

Heiri O, Cremer H, Engels S, Hoek WZ, Peeters W, Lotter AF (2007b) Lateglacial summer temperatures in the Northwest European lowlands: a chironomid record from Hijkemeer, the Netherlands. Quat Sci Rev 26:2420-2437

Hofmann W (1983a) Stratigraphy of Cladocera and Chironomidae in a core from a shallow North German lake. Hydrobiologia 103:235-239

Hofmann W (1983b) Stratigraphy of fossil Chironomidae and Ceratopogonidae (Insecta: Diptera) in Late Glacial littoral sediments from Lobigensee (Swiss Plateau). Rev Paléobiol 2:205-209

Hofmann W (2001) Late Glacial/Holocene succession of the chironomid and cladoceran fauna of the Soppensee (Central Switzerland). J Paleolimnol 25:411-420

Hofmann W, Winn K (2000) The littorina transgression in the Weestern Baltic sea as indicated by subfossil Chironomidae (Diptera) and Cladocera (Crustacea). Int Rev Hydrobiol 85:267-291

Hormes A, Müller BU, Schlüchter C (2001) The Alps with little ice: evidence from eight Holocene phases of reduced glacier extent in the Central Swiss Alps. Holocene 11:255-265

Ilyashuk B, Gobet E, Heiri O, Lotter AF, van Leeuwen JFN, van der Knaap WO, Ilyashuk E, Oberli F, Ammann B (2009) Late Glacial environmental and climatic changes at the Maloja Pass, Central Swiss Alps, as recorded by chironomids and pollen. Quat Sci Rev 28:1340-1353

Isarin RFB (1998) Permafrost distribution and temperatures in Europe during the Younger Dryas. Permafr Periglac Process 8:313-333

Ivy-Ochs S, Schlüchter C, Kubik PW, Denton GH (1999) Moraine exposure dates imply synchronous Younger Dryas glacier advances in the European Alps and in the southern Alps of New Zealand. Geogr Ann 81:313-323

Jones TP, Fortier SM, Pentecost A, Collinson ME (1996) Stable carbon and oxygen isotopic composition of recent charophyte oosporangia and water from Malham Tarn, UK: palaeontological implications. Biogeochemistry 34:99-112

Juggins S (1991) ZONE software, version 1.2. Newcastle University, Newcastle

Juggins S (2003) C2 Program. University of Newcastle, UK

Koç N, Eystein J, Haflidason H (1993) Palaeoceanographic reconstructions of surface ocean conditions in the Greenland, Iceland and Norwegian seas through the last $14 \mathrm{ka}$ based on diatoms. Quat Sci Rev 12:115-140

Kofler W, Krapf V, Oberhuber W, Bortenschlager S (2005) Vegetation responses to the $8200 \mathrm{cal}$. BP cold event and to long-term climatic changes in the Eastern Alps: possible influence of solar activity and North Atlantic freshwater pulses. Holocene 15:779-788

Korhola A, Olander H, Blom T (2000) Cladoceran and chironomid assemblages as quantitative indicators of water depth in subarctic Fennoscandian lakes. J Paleolimnol 24:43-54

Korhola A, Vasko K, Toivonen HTT, Olander H (2002) Holocene temperature changes in northern Fennoscandia reconstructed from chironomids using Bayesian modelling. Quat Sci Rev 21:1841-1860
Kurek J, Cwynar LC, Spear RW (2004) The 8200 cal yr BP cooling event in eastern North America and the utility of midge analysis for Holocene temperature reconstructions. Quat Sci Rev 23:627-639

Lami A, Guilizzoni P, Ryves D, Jones PD, Marchetto A, Battarbee RW, Belis CA, Bettinetti R, Manca M, Comoli P, Nocentini A, Langone L (1997) A Late Glacial and Holocene record of biological and environmental changes from the Crater Lake Albano, central Italy: an interdisciplinary European project (PALICLAS). Water Air Soil Pollut 99:601-613

Larocque I (2001) How many chironomid head capsules are enough? A statistical approach to determine sample size for palaeoclimatic reconstructions. Palaeogeogr Palaeoclimatol Palaeoecol 172:133-142

Larocque I, Finsinger W (2008) Late-Glacial temperature reconstruction using chironomids preserved in Lago Piccolo di Avigliana in the Southern Alps. Palaeogeogr Palaeoclimatol Palaeoecol 257:207-223

Larocque I, Hall RI (2003) Chironomids as quantitative indicators of mean July air temperature: validation by comparison with century-long meteorological records from northern Sweden. J Paleolimnol 29:475-493

Larocque I, Hall RI (2004) Holocene temperature estimates and chironomid community composition in the Abisko Valley, northern Sweden. Quat Sci Rev 23:2453-2465

Larocque I, Rolland N (2006) Le guide visual des chironomids sub-fossiles, du Québec à l'île d'Ellesmere. Institut National de Recherche Scientifique, Rapport de Recherche R-900, ISBN 2-89146-430-3

Larocque I, Hall RI, Grahn E (2001) Chironomids as indicators of climate change: a 100-lake training set from a subarctic region of northern Sweden (Lapland). J Paleolimnol 26:307-322

Larocque I, Pienitz R, Rolland N (2006) Factors influencing the distribution of chironomids in lakes distributed along a latitudinal gradient in northwestern Quebec, Canada. Can J Fish Aquat Sci 63:1286-1297

Larocque I, Grosjean M, Heiri O, Bigler C, Blass A (2009) Comparison between chironomid-inferred July temperatures and meteorological data AD 1850-2001 from varved Lake Silvaplana, Switzerland. J Paleolimnol 41:329-342

Lemdahl G (2000) Lateglacial and early Holocene insect assemblages from sites at different altitudes in the Swiss Alps- implications on climate and environment. Palaeogeogr Palaeoclimatol Palaeoecol 159:293-312

Liikanen A, Murtoniemi T, Tanskanen H, Vaisanen T, Martikainen PJ (2002) Effects of temperature and oxygen availability on greenhouse gas and nutrient dynamics in sediment of a eutrophic mid-boreal lake. Biogeochemistry 59:269-286

Lindberg B (1970) Tanytarsini (Diptera, Chironomidae) from northern Fennoscandia. Ann Zool Fenn 7:303-312

Lotter AF, Birks HJB, Hofmann W, Marchetto A (1998) Modern diatom, cladocera, chironomid, and chrysophyte cyst assemblages as quantitative indicators for the reconstruction of past environmental conditions in the Alps. II. Nutrients. J Paleolimnol 19:443-463

Lotter AF, Birks HJB, Eicher U, Hofmann W, Schwander J, Wick L (2000) Younger Dryas and Allerod summer temperatures at Gerzensee (Switzerland) inferred from 
fossil pollen and cladocerean assemblages. Palaeogeogr Palaeoclimatol Palaeoecol 159:349-361

Luoto TP, Nevalainen L, Sarmaja-Korjonen K (2008) Multiproxy evidence for the 'Little Ice Age' from Lake Hampträsk, Southern Finland. J Paleolimnol 40:1097-1113

Magny M, Aalbersberg G, Bégeot C, Benoit-Ruffaldi P, Bossuet G, Disnar J-R, Heiri O, Laggoun-Defarge F, Mazier F, Millet L, Peyron O, Vannière B, Walter-Simonnet A-V (2006) Environmental and climatic changes in the Jura mountains (eastern France) during the Lateglacial-Holocene transition: a multi-proxy record from Lake Lautrey. Quat Sci Rev 25:414-445

McDermott F, Mattey DP, Hawkesworth C (2001) Centennialscale Holocene climate variability revealed by a highresolution speleothem $\partial^{18} \mathrm{O}$ record from SW Ireland. Science 294:1328-1331

O'Connell M, Huang CC, Eicher U (1999) Multidisciplinary investigations, including stabe-isotope studies, of thick Late Glacial sediments from Tory Hill, Co. Limerick, western Ireland. Palaeogeogr Palaeoclimtol Palaeoecol 147:169-208

Olander H, Birks HJB, Korhola A, Blom T (1999) An expanded calibration model for inferring lake water and air temperatures from fossil chironomid assemblages in northern Fennoscandia. Holocene 9:279-294

Oliver DR, Roussel ME (1983) The insects and arachnids of Canada. Part II. The genera of larval midges of Canada. Publication 1746. Agriculture Canada, 263 pp

Palmer S, Walker IR, Heinrichs M, Hebda R, Scudder G (2002) Postglacial midge community change and Holocene palaeotemperature reconstructions near treeline, southern British Columbia (Canada). J Paleolimnol 28:469-490

Patzelt G (1977) Der zeitliche Ablauf und das Ausmass postglazialer Klimaschwankungen in den Alpen. In: Frenzel B (ed) Dendrochronologie und postglaziale Klimaschwankungen in Europa, Erdwissenschaftliche Forschung 13:249-259

Porinchu DF, Cwynar LC (2000) The distribution of freshwater Chironomidae (Insecta: Diptera) across treeline near the Lower Lena River, Northeast Siberia. Arct Antarct Alp Res 32:429-437

Porinchu DF, Cwynar LC (2002) Late-Quaternary history of midge communities and climate from a tundra site near the lower Lena River, Northeast Siberia. J Paleolimnol 27:59-69

Porinchu D, Rolland N, Moser K (2009) Development of chironomid-based air temperature inference model for the Central Canadian Arctic: incorporating high resolution gridded climate data. J Paleolimnol 41:349-368

Quinlan R, Smol JP (2002) Regional assessment of long-term hypolimnetic oxygen changes in Ontario (Canada) shield lakes using subfossil chironomids. J Paleolimnol 27:249260

Ramsey CB (1995) Radiocarbon calibration and analysis of stratigraphy: the OxCal program. Radiocarbon 37:425-430

Reiss F, Germeister R (1984) Corynocera ambigua Zetterstedt als Glazialrelikt im Starnberger See, Oberbayern. Nachricht Bayerisch Entomol 33:58-61

Rieradevall M, Brooks SJ (2001) An identification guide to subfossil Tanypodinae larvae based on cephalic setation. J Paleolimnol 25:81-99
Rosén P, Segerström U, Eriksson L, Renberg I, Birks HJB (2001) Holocene climate change reconstructed from diatoms, chironomids, pollen and near-infrared spectroscopy at an alpine lake (Sjuodjijaure) in northern Sweden. Holocene 11:551-562

Sarmaja-Korjonen K, Nyman M, Kultii S, Väliranta M (2006) Paleolimnological development of Lake Njagajavri, northern Finnish Lapland, in a changing Holocene climate and environment. J Paleolimnol 35:65-81

Schnell OA, Willasen E (1996) The chironomid (Diptera) communities in two sediment cores from Store Hovvatn, S. Norway, an acidified lake. Ann Limnol 32:45-61

Schwander J, Eicher U, Ammann B (2000) Oxygen isotopes of lake marl at Gerzensee and Leysin (Switzerland), covering the Younger Dryas and two minor oscillations, and their correlation to the GRIP ice core. Palaeogeogr Palaeoclimatol Palaeoecol 159:203-214

Staubli P (1998) Bericht zum Hochmoor-Regenerationsprojekt Egelsee. Amt für Raumplanung, Baudirektion des Kantons Zug, Zug, p 22

Stefanova I, Ognjanova-Rumenova N, Hofmann W, Ammann B (2003) Late Glacial and Holocene environmental history of the Pirin Mountains (SW Bulgaria): a paleolimnological study of Lake Dalgoto (2310 m). J Paleolimnol 30:95-111

Stuiver M, Reimer PJ, Bard E, Beck JW, Burr GS, Hughen KA, Kromer B, McCormac G, Van der Plicht J, Spurk M (1998) INTCAL98 radiocarbon age calibration, 24,0000 cal BP. Radiocarbon 40:1041-1083

Tinner W, Lotter AF (2001) Central European vegetation reponse to abrupt climate change at $8.2 \mathrm{ka}$. Geology 29:551-554

Velle G, Larsen J, Eide W, Peglar SM, Birks HJB (2005a) Holocene environmental history and climate of Ratasjoen, a low alpine lake in south-central Norway. J Paleolimnol 33:129-153

Velle G, Brooks SJ, Birks HJB, Willassen E (2005b) Chironomids as a tool for inferring Holocene climate: an assessment based on six sites in southern Scandinavia. Quat Sci Rev 24:1429-1462

von Grafenstein U, Erlenkeuser H, Brauer A, Jouzel J, Johnsen SJ (1999) A mid-European decadal isotope-climate record from 15, 500 to 5000 years B.P. Science 284:1654-1657

von Grafenstein U, Eicher U, Erlenkeuser H, Ruch P, Schwander J, Ammann B (2000) Isotope signature of the Younger Dryas and two minor oscillations at Gerzensee (Switzerland); palaeoclimatic and palaeolimnologic interpretation based on bulk and biogenic carbonates. Palaeogeogr Palaeoclimatol Palaeoecol 159:215-229

Walker IR (1990) Modern assemblages of arctic and alpine Chironomidae as analogues for Late Glacial communities. Hydrobiologia 214:223-227

Walker IR, MacDonald GM (1995) Distributions of Chironomidae (Insecta: Diptera) and other freshwater midges with respect to treeline, Northwest Territories, Canada. Arctic Alpine Res 27:258-263

Walker IR, Levesque AJ, Cwynar LC, Lotter AF (1997) An expanded surface-water palaeotemperature inference model for use with fossil midges from eastern Canada. J Paleolimnol 18:165-178 
Wehrli M, Tinner W, Ammann B (2007) 16, 000 years of vegetation and settlement history from Egelsee (Menzingen, central Switzerland). Holocene 17:747-761

Wick L, Tinner W (1997) Vegetation changes and timberline fluctuations in the Central Alps as indicators of Holocene climatic oscillations. Arct Alp Res 29: $445-458$
Wiederholm T (ed) (1983) Chironomidae of the Holartic Region. Keys and Diagnoses. Part 1-Larvae. Entomol Scand (Supplement 19) $457 \mathrm{pp}$

Wyssling G, Eikenberg J (2000) Die Höllgrotten bei Baar (Kanton Zug), Entstehungsgeschichte und Altersbestimmung an Quelltuffen. Vierteljahrsschrift der Naturforschenden Gesellschaft in Zürich 145:13-30 